ISSN: 2757-6485

$2021 \& 2$ (3)

\title{
Beden Eğitimi ve Spor Öğretmeni Adaylarının Değerler Eğitimine Yönelik Tutumlarının İncelenmesi
}

\author{
"Examining the Attitudes towards Values Education of Physical Education and \\ Sports Pre-Service Teachers"
}

\section{Dilek YALIZ SOLMAZ \\ ARAŞTIRMA MAKALESI \\ Tarihçe \\ Yayın Geliş Tarihi: 20 Ekim 2021 \\ Kabul Tarihi: 23 Kasim 2021 \\ Online Yayın Tarihi: 30 Aralık 2021}

\section{\&}

DOI: $\underline{\text { http://dx.doi.org/10.29228/anatoliasr.18 }}$

\section{Yazarlarla İletișim \\ 1- (Sorumlu Yazar) Physical Education and Sports Teacher Education Department of Eskisehir Technical University dilekyaliz@eskisehir.edu.tr \\ https://orcid.org/0000-0003-0497-215X \\ 2- Coach Training Department of Eskisehir \\ Technical University \\ gaydin@eskisehir.edu.tr \\ https://orcid.org/0000-0002-6418-9848 \\ 3- Physical Education and Sports Teacher \\ Education Department of Eskisehir Technical \\ University \\ goncaeren@eskisehir.edu.tr \\ https://orcid.org/0000-0001-9787-9098 \\ 4- Physical Education and Sports Teacher \\ Education Department of Eskisehir Technical \\ University \\ cemrelofcaa@gmail.com \\ https://orcid.org/0000-0002-0137-5790}

\section{Yazar Katkıları}

Tüm yazarlar çalışmanın konseptine ve tasarımına katkıda bulundu.

Finansman

$\mathrm{Bu}$ çalışma herhangi bir kurum/kuruluştan maddi destek almadı.

Cıkar Catıșması

Yazarlar çıkar çatışması olmadığını beyan ediyorlar.

Şeffaflık

Yazarlar, çalışmada hiçbir hayati özelliğin ihmal edilmediğini, dürüst, doğru ve şeffaf bir anlatım ile raporlaştırıldığını ve herhangi bir tutarsızlık olmadığını beyan etmişlerdir.

Etik

$\mathrm{Bu}$ çalışmada bilimsel etik kriterlerine uyulmuștur.

\section{Referans Gösterimi}

Yalız Solmaz, D., Güven, G., Eren, G., Akkoyun, C.N. (2021). Beden Eğitimi ve Spor Öğretmeni Adaylarının Değerler Eğitimine Yönelik Tutumlarının İncelenmesi, Anatolia Sport Research, 2(3): 18-29.

Copyright (C) 2021 by Anatolia Sport Research
OZET

Amaç: $\mathrm{Bu}$ araştırma, beden eğitimi ve spor öğretmeni adaylarının değerler eğitimine ilişkin tutumlarını incelemeyi amaçlamaktadır.

Materyal ve Metod: Araştırma kapsamında tarama modelinde betimsel araştırma deseni kullanılmıştır. Araştırmanın örneklemini Eskişehir Teknik Üniversitesi Beden Eğitimi ve Spor Öğretmenliği Bölümünde öğrenim gören 118 öğretmen adayı oluşturmuștur. Araștırmada öğretmen adaylarının değerler eğitimine yönelik tutumları "Değerler Eğitimine Yönelik Tutum Ölçeği (DETÖ)" ile elde edilmiştir. İstatistiksel analizlerde SPSS-23 programı kapsamında t-testi ve tek yönlü varyans (ANOVA) analizlerinden yararlanılmıştır.

Bulgular: Bulgular ışığında, öğretmen adaylarının değerler eğitimine yönelik tutum düzeylerinin, değer eğitimini içselleştirme, değer eğitiminin gereğine inanç ve değer eğitimine yönelik olumlu inanç alt boyutlarında sınıf, yaş ve anne-baba eğitim düzeyine göre değişmediği görülürken, öğretmen adaylarının sadece değer eğitimine yönelik olumlu inanç alt boyutunda cinsiyete göre anlamlı bir farklılık gösterdiği saptanmıştır. Genel olarak öğretmen adaylarının değerler eğitimine yönelik tutum puanlarının ortalamanın üzerinde olduğu ve en yüksek puan ortalamasının "Değer Eğitimine Yönelik Olumlu İnanç" boyutunda olduğu en düşük puan ortalamasının ise "Değerler Eğitimini İçselleştirme" boyutunda olduğu görülmüştür.

Sonuç: Beden eğitimi öğretmenlerinin ve öğretmen adaylarının değerler eğitimine yönelik olumlu tutuma sahip olmaları, beden eğitimi ve spor dersinde değerler eğitimi uygulamalarının etkililiğini arttırması bakımından olumlu bir sonuç olarak değerlendirilebilir.

Anahtar Kelimeler: Beden Eğitimi, Değerler Eğitimi, Öğretmen Adayları, Tutum.

\section{ABSTRACT}

Aim: This study aims to examine the attitudes of physical education and sports pre-service teachers towards values education.

Material and Method: Within the scope of the research, the descriptive research design was used in the survey model. The participants of the study consisted of 118 pre-service teachers studying at the Department of Physical Education and Sports Teaching at Eskisehir Technical University. In the study, the attitudes of pre-service teachers towards values education were obtained with the "Attitude Scale Towards Values Education" (DETS). In statistical analysis, t-test and one-way analysis of variance (ANOVA) analyzes were used within the scope of the SPSS-23 program. Results: In the light of the findings, it is seen that the attitudes of pre-service teachers towards values education do not change according to class, age, and parental education level in the subdimensions of internalizing values education, belief in the necessity of values education, and positive belief in values education, while the prospective teachers only have positive belief in values education sub-dimensions. It was found that there was a significant difference according to gender. In general, it was seen that the attitude scores of the pre-service teachers towards values education were above the average and the highest average score was in the "Positive Belief in Values Education" dimension, and the lowest average score was in the "Internalizing Values Education" dimension.

Conclussions: The positive attitude of physical education teachers and pre-service teachers towards values education can be evaluated as a positive result in terms of the effectiveness of values education practices in physical education and sports lessons.

Keywords: Attitude, Physical Education, Pre-service Teachers, Values Education. 


\section{GíRiş}

Son yıllarda popüler bir araştırma konusu olan değerler eğitimi, temel olarak tüm toplumlarda geçmişten beri verilen bir eğitimdir. Değerler eğitimi içerisinde yer alan toplumların, kültürel değerlerini yeni nesillere taşımak ve iyi davranışlar kazandırmak, çocukları terbiye etmek gibi amaçları geçmişten günümüze var olmuştur (Yıldırım, 2019). Bilim ve teknolojideki gelişmeler birey yaşamında büyük bir öneme sahipken; değerler, bireysel davranışı şekillendirme, yönlendirme ve toplumsal kurumların işleyişini etkileme bakımından çok daha önemli bir yere sahiptir (Çetin, 2018).

Alanyazında değerlerin, öğrenilen veya öğretilebilen bir yapıda olması, bireysel, kültürel veya toplumsal açıdan ele alınması, değiştirilebilir veya kalıcı bir özellik taşıması gibi birçok farklı açıdan betimlendiği görülebilir. Bununla birlikte söz konusu eğitim için alanyazında kullanılan diğer terimler, değerler eğitimi, ahlak eğitimi veya karakter eğitimi olarak karşımıza çıkabilmektedir (Yıldırım, 2019).

Dolaylı veya dolaysız olarak bireylerin davranışları değerler tarafindan yönlendirilmektedir (Özgüven, 1994). Ayrıca kültürün nesilden nesile aktarımı için gerekli olan değer kavramı, toplumdaki ortak bağı kuvvetlendirici, toplumsal çözülmeyi engelleyici bir yapıya da sahiptir. Değer kavramı, toplumun sahip olduğu özellikleri belirli bir standart veya ölçüt haline getirmesi açısından önemlidir (Yıldırım, 2019).

Değer kavramının, alanyazında birçok çalışmaya konu olmasına karşın yeterli düzeyde açıklı̆̆a kavuşturulduğunu söylemek zordur (Aladağ ve Kuzgun, 2015). Günümüzde, neyin değer kavramı olarak nitelendirileceği veya nitelendirilemeyeceğine ilişkin karmaşanın halen devam ettiği görülmektedir. Bu karmaşanın altında yatan sebebin, inanç, tutum, norm gibi benzer kavramlarla değer kavramının yakın ilişki içerisinde olmasından kaynaklandığı söylenebilir. Söz konusu kavramlardan ilki olan ve olumlu ya da olumsuz olarak değişebilen tutumlar, nesne veya amaçların, iyi ya da kötü, arzu edilir ya da istenmeyen olarak değerlendirilmesi şeklinde tanımlanabilir. Değerler ise, tutumların altında yatan bir olgu olarak tanımlanabilir (Yıldırım, 2019).

Türk Dil Kurumu (TDK)'na göre değer kavramı; “bir şeyin değdiği karş1lık veya kıymet, bir şeyin önemini belirlemeye yarayan soyut ölçü, bir ulusun sahip olduğu bilimsel, sosyal, kültürel ve ekonomik değerlerini kapsayan maddi ve manevi ögelerin bütünü şeklinde tanımlanmaktadır” (TDK, 2015). Diğer bir ifadeyle, toplumların yaradılışında ve birlikteliklerinin sürdürülmesinde ortak değerlerin önemli bir rolü vardır. Ortak değerler, ortak amaç ve ihtiyaçların, yaşayış ve inanışın bir ürünüdür (Alyılmaz ve Alyılmaz, 2014). Sonuç olarak, değerler iyi ve kötüyü ayırmamızda bize yol gösteren, gösterdiği bu yolda ilerlerken tavırlarımızı ve kişiliğimizi tanımlayan ve aynı zamanda etkileyen, yaşamımızdaki önemli soyut olgulardır (Aladağ ve Kuzgun, 2015).

Değerler doğuştan değil, yaşantılar ile kazanılırlar. Bu açıdan değerlerin kazanımı eğitim süreçleri kapsamındadır (Coşkunserçe, 2020). Bireyi belirlenen amaçlara ulaştırma süreci olan eğitim sürecinde, bireyler bilgi ve beceri ile birlikte değer ve tutumlar da kazanır. Bilgi, beceri, değer ve tutumlar kazanan bireyler toplumsal yapıda değişiklikler meydana getirirler (Ergün, 1994). Eğitimin amaçlarından biri de toplumun çoğunluğu tarafindan kabul edilmiş değerleri gelecek nesillere aktarmak ve onların bu değerlerini içselleştirmelerini sağlamaktır (Koç ve Budak, 2021). Eğitim toplumdaki değerlerin nesilden nesile aktarılmasında önemli bir yere sahiptir. Bireylerin kişiliğini şekillendiren, tutum ve davranışlarına yol gösteren, hayata bakış açısını oluşturan öğelerden biri değerlerdir. Bu sebeple her bireyin evrensel olarak kabul edilen değerlerin farkına varması, onları içselleştirmesi ve bu değerleri kişilik haline dönüştürmesi gerekir. Bireyin hayatı boyunca devam eden bu değer edinme sürecine ise değerler eğitimi denir (Köylü, 2016). Artan toplumsal şiddet ve ahlaki yozlaşma; ahlaki değerlere, nezaket kurallarına 
ve temizlik kurallarına uyulmaması değerler eğitimine olan ihtiyacı daha da artırmaktadır (Coşkunserçe, 2020). Değerler eğitiminin özü, öğrenciye hayattaki “neden?" ve "ne için?” sorusunu sormada yardımc1 olmaktır (Yıldırım, 2019). Değerler eğitimi ailede başlamakta, okullarda ise daha sistemli bir süreç kazanmaktadır. Okul, öğrencilerin evrensel değerler ile birlikte içinde bulundukları toplumun yerel değerlerini de kazanmasına yardımcı olmaktadır (Çetin, 2018). Eğitimin temel hedefleri arasında öğrencilerin akademik bilgi düzeylerini arttırmak ve öğrencilere yeni beceriler kazandırmanın yanında, değerler eğitimi de yer almaktadır. Çünkü toplumdaki bireyleri birbirine bağlayan ve bir toplumun bir arada yaşayabilmesini sağlayan önemli etmenlerden biri de değerlerdir (Coşkunserçe, 2020). Değer eğitiminin amacı, ahlaki değerlere ve sorumluluk duygusuna sahip bireyler yetiştirmektir. Bu nedenle insanlar değer eğitimi yoluyla saygı, sevgi, sorumluluk, cesaret, azim, inanç, adalet ve erdem gibi değerleri elde etmeye çalışırlar (Altan, 2011; Kulaksızoğlu ve Dilmaç, 2000). Bu nedenle okullar, özellikle öğretmenler, değerler eğitimi sürecinde önemli bir rol oynamaktadır (Çetin, 2018).

Öğretmenler, öğrencilerin değerlere karşı duyarlılıklarını geliştirmede ve farkındalıklarını artırmada doğrudan veya dolaylı olarak önemli bir rol oynamaktadır (Yalar, 2010). Ancak öğretmenler, öğretim faaliyetlerinde uygulanması istenilen değerlere kendileri sahip değillerse, öğrencilere iyi bir rol model değil, aksine öğrencilerde bulunan mevcut değerlerin körelmesine ve hatta ortadan kalkmasına neden olabilecek olumsuz bir rol model olabilirler (Yazıc1, 2006). Eğitim ve öğretim faaliyetlerini yürüten öğretmenlerin, kazandırmaya çabaladıkları kavramları öncelikle kendilerinin benimsemesi ve anlaması, diğer bir ifade ile değerin ne anlama geldiğini kavraması önemlidir (Yıldırım, 2019). Bu sebeple eğitim sisteminin içerisinde görev alan öğretmen ve görev alacak öğretmen adaylarının değerler eğitiminde daha aktif rol oynayabilmeleri yalnızca bu alandaki bilgi ve becerilerine değil aynı zamanda olumlu tutum geliştirmelerine de bağlıdır. Çünkü bilgi ve beceri ile beraber tutum da öğretimi etkileyen en önemli öğelerden birisi olarak ifade edilmektedir (Kağıtçıbaşı ve Cemalcılar, 2014).

Günümüzde değerler eğitimi giderek önem kazanmaktadır. Milli Eğitim Bakanlığı, 2005 yılından itibaren öğrenciye kazandırılması istenen değerleri, doğrudan veya dolaylı olarak ders programlarına koymuştur (Yıldırım, 2019). Ayrıca değerler eğitimi; birçok bilim dalının inceleme alanına girmiş ve her bilim dalında değerler eğitimi ile ilgili çeşitli araştırmalar yapılmıştır ve hala yapılmaktadır (Şahin, 2019). Bununla beraber alanyazında öğretmen adaylarının değerler ve değerler eğitimi konusunda yeterli eğitim almadıklarını ve gerekli bilgiye sahip olmadıkları ortaya konulmaktadır (Fidan, 2009).

Değerler eğitiminde büyük sorumluluklara sahip olan öğretmenler, değerler eğitiminde yaptıkları ya da yapmadıkları her konuda öğrencilerin değer algılarını olumlu ya da olumsuz yönde etkileyebilirler. Bu sebeple hem öğretmenlerin hem de öğretmen adaylarının değerlerin aktarımı ve hayata geçirilmesi sürecinde değerlere ve değerler eğitimine ilişkin tutumlarının ve görüşlerinin de etkili olduğu düşünülmektedir. Ayrıca öğretmen adaylarının farklı öğretim alanlarındaki tutumlarının belirlenmesi, bu alanların öğretimine ilişkin meslek yaşamlarında gösterecekleri davranış kalıplarının belirlenmesine ve bu doğrultuda istenilen tutum ve davranış eğilimlerinin oluşmasına katkı sağlayacaktır. Buna göre, bu araştırmanın amacı, beden eğitimi ve spor öğretmeni adaylarının değerler eğitimine ilişkin tutumlarını incelemektir. Bu genel amaç kapsamında oluşturulan araştırma soruları şu şekildedir:

1. Beden eğitimi ve spor öğretmeni adaylarının değerler eğitimine yönelik tutum düzeyleri nasıldir?

2. Beden eğitimi ve spor öğretmeni adaylarının değerler eğitimine yönelik tutumlarında, cinsiyet, sınıf düzeyi, yaş, ebeveyn eğitim düzeyi değişkenlerine göre anlamlı bir farklılık var mıdır? 


\section{MATERYAL VE METOD}

\section{Araștırma Modeli}

$\mathrm{Bu}$ çalışmada, tarama modelinde betimsel araştırma deseninden yararlanılmıştır. Fraenkel, Wallen ve Hyun (2018) tarama modelini, geçmişte veya halen var olan bir durumu, var olduğu biçimiyle betimlemeyi amaçlayan araştırma modelleri olarak tanımlamıştır.

\section{Katılımcilar}

Araştırmanın örneklemini Eskişehir Teknik Üniversitesi Beden Eğitimi ve Spor Öğretmenliği Bölümünde öğrenim gören 118 öğretmen adayı oluşturmuştur. Araştırma örnekleminin belirlenmesinde, araştırma amaçları doğrultusunda uygun örnekleme yöntemi (convenience sampling method) kullanılmıştır (Fraenkel, Wallen and Hyun, 2018). Araştırmada veri toplama aracı online platformlar aracılığıyla öğrencilere ulaştırılmış olduğundan tüm sınıf düzeylerinden toplam 118 gönüllü öğretmen adayına uygulanmıştır. Öğrenciler, katılımlarının gönüllük esasına dayalı olduğu, çalışma kayıtlarının gizli tutulacağı ve bireysel katkılarının nihai raporda tanımlanamayacağı konusunda bilgilendirilmiş ve gerekli izinleri alınmıştır. Öğretmen adaylarının demografik bilgilerine ilişkin elde edilen bulgular Tablo 1'de verilmiştir.

Tablo 1. Demografik Bilgiler

\begin{tabular}{|c|c|c|c|}
\hline & & $\mathrm{N}$ & $\%$ \\
\hline \multirow{2}{*}{ Cinsiyet } & Kadın & 56 & 47.5 \\
\hline & Erkek & 62 & 52.5 \\
\hline \multirow{4}{*}{ Sinıf } & 1. $\operatorname{sinif}$ & 31 & 26.3 \\
\hline & 2. $\operatorname{sinif}$ & 30 & 25.4 \\
\hline & 3. $\sin 1 \mathrm{f}$ & 34 & 28.8 \\
\hline & 4. sinıf ve üzeri & 23 & 19.5 \\
\hline \multirow{5}{*}{ Yaş } & 19 yaş ve altı & 29 & 24.6 \\
\hline & 20 yaş & 39 & 33.1 \\
\hline & 21 yaş & 20 & 16.9 \\
\hline & 22 yaş & 10 & 8.5 \\
\hline & 23 yaş ve üstü & 20 & 16.9 \\
\hline \multirow{4}{*}{ Anne eğitim düzeyi } & İlkokul mezunu & 45 & 38.1 \\
\hline & Ortaokul mezunu & 27 & 22.9 \\
\hline & Lise mezunu & 26 & 22.0 \\
\hline & Üniversite mezunu & 20 & 16.9 \\
\hline \multirow{4}{*}{ Baba eğitim düzeyi } & İlkokul mezunu & 21 & 17.8 \\
\hline & Ortaokul mezunu & 24 & 20.3 \\
\hline & Lise mezunu & 34 & 28.8 \\
\hline & Üniversite mezunu & 39 & 33.1 \\
\hline
\end{tabular}

Tablo 1'de görüldüğü gibi araştırmada yer alan öğrencilerin \%47.5'i kadın, \%52.5'i ise erkektir. Öğrencilerin \%26.3'ü 1. sinıfta, \%25.4'ü 2. sinıfta, \%28.8'i 3. sinıfta ve \%19.5'i ise 4. Sinıf ve üzerinde öğrenim görmektedir. Öğrencilerin yaş düzeyleri incelendiğinde, \%24.6's1 19 yaş ve altı, \%33.1'i 20 yaşında, \%16.9'u 21 yaşında, \%8.5'i 22 yaşında ve \%16.9'u ise 23 yaş ve yukarısındadır. Öğrencilerin anne-baba eğitim düzeyleri incelendiğinde \%38.1'inin annesinin ilkokul mezunu olduğu, \%33.1'inin babasının üniversite mezunu olduğu görülmektedir. 


\section{Veri Toplama Aracı}

Araştırmada öğretmen adaylarının değerler eğitimi ile ilgili tutumları "Değerler Eğitimine Yönelik Tutum Ölçeği (DETÖ)" ile elde edilirken, sosyo-demografik bilgilere ilişkin veriler ise araştırmacı tarafından geliştirilmiş "Kişisel Bilgi Formu" ile toplanmıştır. Veri toplama aracına ilişkin açıklamalar aşağıda verilmiştir.

Değerler Eğitimine Yönelik Tutum Ölçeği (DETÖ): Çetin (2018) tarafından geçerlik ve güvenirliği tamamlanmış olan ölçek 5'li likert tipinde (Hiç Katılmıyorum, Katılmıyorum, Kısmen, Katıllyorum, Büyük Ölçüde Katılıyorum, Tamamen Katılıyorum) ve 11'i olumsuz 31 maddeden oluşmaktadır. Üç alt-boyuttan oluşan DETÖ'nün, değer eğitiminin gereğine inanç olarak isimlendirilen birinci alt-boyutu 13 maddeden oluşmakta ve bu alt-boyut değerler eğitiminin inancına yönelik olumlu tutumları yansıtmaktadır. Değer eğitimini içselleştirme olarak adlandırılan ikinci alt-boyut 7 maddeden oluşmakta ve değerler eğitimini benimsemeye yönelik olumlu tutumları yansıtmaktadır. Ölçeğin üçüncü ve son altboyutu olan değer eğitimine yönelik olumsuz inanç alt-boyutu ise 11 maddeden oluşmakta ve değerler eğitimine ilişkin olumsuz tutumları yansıtmaktadır. Puanlama yapılırken "değer eğitimine yönelik olumsuz inanç" alt-boyutu için ters puanlama yapılmıştır. DETÖ'den elde edilebilecek en yüksek puan 155; en düşük puan ise 31 'dir. Ölçekten elde edilen yüksek puanlar değerler eğitimine yönelik olumlu tutumun bir ifadesidir. Yapılan analizler sonucunda Cronbach-alfa iç tutarlılık katsayısı toplam ölçek için 0.95 iken birinci alt-boyut için .91, ikinci alt-boyut için .87, üçüncü alt-boyut için .71 olarak tespit edilmiştir. Sonuç olarak ölçeğin gerekli psikometrik özelliklere sahip bir ölçek olduğuna karar verilmiştir. $\mathrm{Bu}$ araştırmadan elde edilen toplam ölçek için Cronbach-alfa iç tutarlılık katsayısı ise .94 olarak belirlenmiştir. Alt ölçeklerden elde edilen Cronbach-alfa iç tutarlılık katsayıları ise değer eğitiminin gereğine inanç için .89 , değerler eğitimini içselleştirme için .85 , değer eğitimine yönelik olumlu inanç için .75 olarak tespit edilmiştir. "Değerler Eğitimine Yönelik Tutum Ölçeğì”ni hazırlamış olan kişilerden gerekli izinler alınmış ve yazışmaların kayıtları alınmıştır.

Kişisel Bilgi Formu: Araştırmacılar tarafından hazırlanan bu formda, katılımcıların yaş, cinsiyet, sınıf düzeyleri ve ebeveynlerinin eğitim düzeylerine ilişkin sorular yer almaktadır.

\section{Veri Analizi}

İstatistiksel analizlerde SPSS-23 (Statistical Package for Social Sciences) programından kullanılmıştır. Örneklem evrenden bağımsız olarak seçilmiştir. Araştırmadan elde edilen verilerin normal dağılım sergileyip sergilemediğini saptamak amacıyla verilerin basıklık ve çarpıklık değerleri incelenmiştir. Curan, West ve Finch (1996) ile Chou ve Bentler (1995) basıklık ve çarpıklık değerlerinin \pm 2 ve \pm 7 aralıklarında olduğunda, verilerin normal dağılım gösterdiklerini ifade etmişlerdir. Buna göre yapılan analiz sonucunda verilerin normal dağıldığı görülmüştür. Ayrıca verilerin homojenliğini belirlemek amacıyla Levene testi yapılmıştır. Levene testi sonucuna göre verilerin homojen olduğu tespit edilmiştir. Araştırmanın amacına bağlı olarak verileri test etmek için frekans, yüzde, aritmetik ortalama ve standart sapma kullanılmıştır. Ayrıca değişkenler arasında farklılığın olup olmadığını belirlemek için bağımsız gruplar için t-testi ve tek yönlü varyans analizinden (ANOVA) yararlanılmıştır. İstatistiksel analizde anlamlılık düzeyi .05 olarak kabul edilmiştir.

\section{BULGULAR}

Bu bölümde araştırma amacını test etmek için yapılan istatistiksel analizler sonucunda elde edilen bulgulara yer verilmiştir. 
Tablo 2. Betimleyici istatistikler

\begin{tabular}{lrrrrrrr}
\hline & N & Min. & Max. & M & SS & Çarpıklık & Basıklık \\
\hline Değer eğitiminin gereğine inanç & 118 & 2.38 & 5.00 & 3.98 & .61 & -.402 & -.040 \\
\hline Değerler eğitimini içselleştirme & 118 & 1.86 & 5.00 & 3.43 & .66 & .070 & -.079 \\
\hline Değer eğitimine yönelik olumlu inanç & 118 & 1.64 & 5.00 & 4.34 & .61 & -1.517 & 3.444
\end{tabular}

Tablo 2'de öğretmen adaylarının değerler eğitimine yönelik tutumlarına ilişkin betimsel istatistikler incelendiğinde, ölçeğin bütün alt boyutlarından elde edilen puanların ortalamanın üzerinde olduğu görülmektedir. Değerler eğitimine yönelik tutum ölçeğinin alt boyutlarından en yüksek ortalamanın "Değer Eğitimine Yönelik Olumlu İnanç" boyutunda olduğu belirlenmiştir ( $M=4.34)$. "Değer Eğitimine Yönelik Olumlu İnanç" boyutunu ise "Değer Eğitiminin Gereğine İnanç" boyutunun ( $M=3.98)$ takip ettiği ve en düşük ortalamanın "Değerler Eğitimini İçselleştirme" boyutunun ( $M=3.43)$ olduğu görülmektedir.

Tablo 3. Cinsiyete göre değerler eğitimine yönelik tutum alt boyutlarına ilişkin bulgular

\begin{tabular}{|c|c|c|c|c|c|c|}
\hline Faktör & Değişken & $\mathbf{N}$ & $\mathbf{X}$ & SS & $\mathbf{t}$ & $\mathbf{p}$ \\
\hline \multirow{2}{*}{ Değer eğitiminin gereğine inanç } & Kadın & 56 & 3.98 & .59 & \multirow{2}{*}{.040} & \multirow{2}{*}{0.97} \\
\hline & Erkek & 62 & 3.97 & .63 & & \\
\hline \multirow{2}{*}{ Değerler eğitimini içselleştirme } & Kadın & 56 & 3.49 & .68 & \multirow{2}{*}{.936} & \multirow{2}{*}{0.35} \\
\hline & Erkek & 62 & 3.37 & .65 & & \\
\hline \multirow{2}{*}{ Değer eğitimine yönelik olumlu inanç } & Kadın & 56 & 4.49 & .49 & \multirow{2}{*}{2.596} & \multirow{2}{*}{$0.01 *$} \\
\hline & Erkek & 62 & 4.20 & .67 & & \\
\hline
\end{tabular}

$* \mathrm{p}<.05$

Tablo 3 incelendiğinde değer eğitiminin gereğine inanç, değer eğitimini içselleştirme ve değer eğitimine yönelik olumlu inanç boyutlarında kadın öğretmen adaylarının ortalamalarının erkek adaylardan daha yüksek olduğu ortaya çıkmıştır. Öğretmen adaylarının cinsiyetlerine göre değerler eğitimine yönelik tutumlarında farklılık olup olmadığını belirlemek amacıyla yapılan $t$ testi analizi sonucunda, değerler eğitimine yönelik tutum puanları açısından kadın ve erkekler arasında değer eğitiminin gereğine inanç ve değer eğitimini içselleştirme boyutlarında anlamlı bir farklılığın ortaya çıkmadığ görülmüştür (t1 16 = .040, p>0.05; t116 = .936, p>0.05). Buna karşın değer eğitimine yönelik olumlu inanç boyutunda kadınlar lehine istatistiksel olarak anlamlı farklılık ortaya çıktığı görülmüştür $(\mathrm{t} 116=2.596, \mathrm{p}<0.05)$.

Tablo 4. Sinıf düzeyine göre değerler eğitimine yönelik tutum alt boyutlarına ilişkin bulgular

\begin{tabular}{|c|c|c|c|c|c|c|}
\hline Faktör & Değişken & $\mathbf{N}$ & $\mathbf{X}$ & SS & $\mathbf{f}$ & $\mathbf{p}$ \\
\hline \multirow{4}{*}{$\begin{array}{l}\text { Değer eğitiminin gereğine } \\
\text { inanç }\end{array}$} & 1. sinif & 31 & 3.97 & .65 & \multirow{4}{*}{.282} & \multirow{4}{*}{0.83} \\
\hline & 2. sinif & 30 & 4.06 & .53 & & \\
\hline & 3. sinif & 34 & 3.96 & .66 & & \\
\hline & 4. sinıf ve üzeri & 23 & 3.91 & .56 & & \\
\hline \multirow{4}{*}{$\begin{array}{l}\text { Değerler eğitimini } \\
\text { içselleştirme }\end{array}$} & 1. sinif & 31 & 3.39 & .65 & \multirow{4}{*}{.462} & \multirow{4}{*}{0.71} \\
\hline & 2. sinif & 30 & 3.54 & .56 & & \\
\hline & 3. sinif & 34 & 3.41 & .74 & & \\
\hline & 4. sınıf ve üzeri & 23 & 3.34 & .67 & & \\
\hline
\end{tabular}


Değer eğitimine yönelik olumlu inanç

\begin{tabular}{llll} 
1. sinıf & 31 & 4.25 & .65 \\
\hline 2. sinıf & 30 & 4.39 & .62 \\
\hline 3. sinıf & 34 & 4.39 & .53 \\
\hline 4. sinıf ve üzeri & 23 & 4.28 & .62
\end{tabular}

$* \mathrm{p}<.05$

Tablo 4'te, katılımcıların sınıf düzeyinin bağımsız bir değişken ve değerler eğitimine yönelik tutum puanlarının bağımlı değişken olduğu tek yönlü varyans analizi gerçekleştirilmiştir. Sonuçlar, değerler eğitimine yönelik tutum puanları açısından katılımcıların sınıf düzeyleri arasında anlamlı bir farklılık göstermemiştir (değer eğitiminin gereğine inanç, $p>0.05$; değerler eğitimini içselleştirme, $p>0.05$; ve değer eğitimine yönelik olumlu inanç, $\mathrm{p}>0.05$ ).

Tablo 5. Yaşa göre değerler eğitimine yönelik tutum alt boyutlarına ilişskin bulgular

\begin{tabular}{|c|c|c|c|c|c|c|}
\hline Faktör & Değişken & $\mathbf{N}$ & $\mathbf{X}$ & SS & $\mathbf{f}$ & $\mathbf{P}$ \\
\hline \multirow{5}{*}{$\begin{array}{l}\text { Değer } \\
\text { eğitiminin } \\
\text { gereğine inanç }\end{array}$} & 19 yaş ve altı & 29 & 4.01 & .63 & \multirow{5}{*}{.865} & \multirow{5}{*}{.48} \\
\hline & 20 yaş & 39 & 3.95 & .56 & & \\
\hline & 21 yaş & 20 & 3.80 & .59 & & \\
\hline & 22 yaş & 10 & 3.97 & .72 & & \\
\hline & 23 yaş ve üstü & 20 & 4.15 & .59 & & \\
\hline \multirow{5}{*}{$\begin{array}{l}\text { Değerler } \\
\text { eğitimini } \\
\text { içselleştirme }\end{array}$} & 19 yaş ve altı & 29 & 3.51 & .63 & \multirow{5}{*}{.940} & \multirow{5}{*}{.44} \\
\hline & 20 yaş & 39 & 3.29 & .59 & & \\
\hline & 21 yaş & 20 & 3.34 & .63 & & \\
\hline & 22 yaş & 10 & 3.60 & .69 & & \\
\hline & 23 yaş ve üstü & 20 & 3.55 & .81 & & \\
\hline \multirow{5}{*}{$\begin{array}{l}\text { Değer } \\
\text { eğitimine } \\
\text { yönelik olumlu } \\
\text { inanç }\end{array}$} & 19 yaş ve altı & 29 & 4.33 & .68 & \multirow{5}{*}{1.353} & \multirow{5}{*}{.25} \\
\hline & 20 yaş & 39 & 4.34 & .48 & & \\
\hline & 21 yaş & 20 & 4.15 & .60 & & \\
\hline & 22 yaş & 10 & 4.19 & .90 & & \\
\hline & 23 yaş ve üstü & 20 & 4.57 & .48 & & \\
\hline
\end{tabular}

$$
* \mathrm{p}<.05
$$

Tablo 5 'te, katılımcıların yaş düzeylerine göre değerler eğitimine yönelik tutum puanları arasında farklılık olup olmadığını belirlemek amacıyla tek yönlü varyans analizi gerçekleştirilmiştir. Sonuçlar, değerler eğitimine yönelik tutum puanları açısından katılımcıların yaş düzeyleri arasında anlamlı bir farklılık göstermemiştir (değer eğitiminin gereğine inanç, $\mathrm{p}>0.05$; değerler eğitimini içselleştirme, $\mathrm{p}>0.05$; ve değer eğitimine yönelik olumlu inanç, $\mathrm{p}>0.05$ ).

Tablo 6. Anne eğitim düzeyine göre değerler eğitimine yönelik tutum alt boyutlarına ilişkin bulgular

\begin{tabular}{|c|c|c|c|c|c|c|}
\hline Faktör & Değişken & $\mathbf{N}$ & $\mathbf{X}$ & ss & f & $\mathbf{P}$ \\
\hline \multirow{4}{*}{$\begin{array}{l}\text { Değer } \\
\text { eğitiminin } \\
\text { gereğine inanç }\end{array}$} & İlkokul & 45 & 4.09 & .49 & \multirow{4}{*}{.830} & \multirow{4}{*}{.48} \\
\hline & Ortaokul & 27 & 3.91 & .62 & & \\
\hline & Lise & 26 & 3.88 & .68 & & \\
\hline & Üniversite & 20 & 3.93 & .71 & & \\
\hline \multirow{4}{*}{$\begin{array}{l}\text { Değerler } \\
\text { eğitimini } \\
\text { içselleştirme }\end{array}$} & İlkokul & 45 & 3.55 & .49 & \multirow{4}{*}{.888} & \multirow{4}{*}{.45} \\
\hline & Ortaokul & 27 & 3.36 & .68 & & \\
\hline & Lise & 26 & 3.32 & .75 & & \\
\hline & Üniversite & 20 & 3.36 & .81 & & \\
\hline
\end{tabular}




\begin{tabular}{|c|c|c|c|c|c|c|}
\hline \multirow{4}{*}{$\begin{array}{l}\text { Değer } \\
\text { eğitimine } \\
\text { yönelik olumlu } \\
\text { inanç }\end{array}$} & İlkokul & 45 & 4.37 & .64 & \multirow{4}{*}{.903} & \multirow{4}{*}{.44} \\
\hline & Ortaokul & 27 & 4.29 & .63 & & \\
\hline & Lise & 26 & 4.20 & .59 & & \\
\hline & Üniversite & 20 & 4.48 & .48 & & \\
\hline
\end{tabular}

Tablo 6'da görüldüğü üzere öğretmen adaylarının anne eğitim düzeylerinin, değerler eğitimine yönelik tutumlarında farklılık gösterip göstermediğini tespit etmek amacıyla ANOVA testi yapılmıştır. Ulaşılan sonuçlarda, öğretmen adaylarının anne eğitim düzeyleri ile değerler eğitimine yönelik tutum puanları arasında istatistiksel olarak anlamlı farklılığın ortaya çıkmadığı görülmüştür $(p>0.05)$.

Tablo 7. Baba eğitim düzeyine göre değerler eğitimine yönelik tutum alt boyutlarına ilişkin bulgular

\begin{tabular}{|c|c|c|c|c|c|c|}
\hline Faktör & Değişken & $\mathbf{N}$ & $\mathbf{X}$ & SS & $\mathbf{f}$ & $\mathbf{P}$ \\
\hline \multirow{4}{*}{$\begin{array}{l}\text { Değer } \\
\text { eğitiminin } \\
\text { gereğine inanç }\end{array}$} & İlkokul & 21 & 4.23 & .49 & \multirow{4}{*}{2.119} & \multirow{4}{*}{.10} \\
\hline & Ortaokul & 24 & 3.79 & .64 & & \\
\hline & Lise & 34 & 4.00 & .56 & & \\
\hline & Üniversite & 39 & 3.93 & .64 & & \\
\hline \multirow{4}{*}{$\begin{array}{l}\text { Değerler } \\
\text { eğitimini } \\
\text { içselleştirme }\end{array}$} & İlkokul & 21 & 3.69 & .69 & \multirow{4}{*}{1.562} & \multirow{4}{*}{.20} \\
\hline & Ortaokul & 24 & 3.29 & .69 & & \\
\hline & Lise & 34 & 3.38 & .57 & & \\
\hline & Üniversite & 39 & 3.40 & .67 & & \\
\hline \multirow{4}{*}{$\begin{array}{l}\text { Değer } \\
\text { eğitimine } \\
\text { yönelik olumlu } \\
\text { inanç }\end{array}$} & İlkokul & 21 & 4.38 & .77 & \multirow{4}{*}{.878} & \multirow{4}{*}{.45} \\
\hline & Ortaokul & 24 & 4.17 & .61 & & \\
\hline & Lise & 34 & 4.42 & .46 & & \\
\hline & Üniversite & 39 & 4.33 & .60 & & \\
\hline
\end{tabular}

Tablo 7'de görüldügü üzere öğretmen adaylarının baba eğitim düzeylerinin, değerler eğitimine yönelik tutumlarında farklılık gösterip göstermediğini tespit etmek amacıyla tek yönlü varyans analizi yapılmıştır. Ulaşılan sonuçlarda, öğretmen adaylarının baba eğitim düzeyleri ile değerler eğitimine yönelik tutum puan ortalamaları arasında istatistiksel olarak anlamlı farklılığın ortaya çıkmadığı görülmüştür ( $p>0.05)$.

\section{TARTISQMA VE SONUÇ}

Araştırmadan amaçları doğrultusunda elde edilen birinci sonuç, öğretmen adaylarının değerler eğitimine yönelik tutum düzeylerine yöneliktir. Bu sonuca göre öğretmen adaylarının değerler eğitimine yönelik tutum puanlarının ortalamanın üzerinde olduğu ve en yüksek puan ortalamasının "Değer Eğitimine Yönelik Olumlu İnanç" boyutunda olduğu, en düşük puan ortalamasının ise "Değerler Eğitimini İçselleştirme" boyutunda olduğu görülmektedir. Alanyazında beden eğitimi ve spor öğretmen adaylarının değerler eğitimine yönelik tutumlarını araştıran herhangi bir araştırmaya ulaşılmamakla birlikte, bu araştırmada elde edilen sonuca paralel olarak Yaşaroğlu'nun (2014) sinıf öğretmenleriyle yürüttüğü çalışmada öğretmenlerin değerler eğitimine yönelik tutumlarının olumlu olduğu görülmektedir. Yazıcı'nın (2013) öğretmenler üzerinden yapmış olduğu araştırmada katılımcıların değerler eğitimine yönelik görüşlerinin olumlu düzeyde olduğu belirlenmiştir. Y1lmaz ve Y1lmaz (2017) tarafindan yapılan araştırmadan elde edilen sonuçlara göre öğretmenlerin değerler eğitimine bakış açılarının olumlu düzeyde olduğu ortaya çıkmıştır. Blase (1983) tarafından yapılan araştırmada 
öğretmenlerin temel değerleri öğretmeyi öğretmenliğin asli görevi ve mesleğe ilişkin doyum ve ödülün temel dayană̆ 1 olarak gördükleri ortaya çıkmıştır. Benzer şekilde, Kozikoğlu (2018), okulöncesi öğretmenleri üzerinde yaptığı araştırma sonucunda, değerler eğitimine yönelik okulöncesi öğretmenlerinin tutumlarının olumlu olduğu sonucuna varmıştır. Tutumların bireysel davranış ve uygulamalar üzerinde önemli bir etkiye sahip olduğu dikkate alındığında (Al Mamun et al., 2012; İlhan ve Karataş, 2015), beden eğitimi ve spor öğretmenleri ve adaylarının değerler eğitimine yönelik olumlu tutuma sahip olmaları, beden eğitimi ve spor dersinde değerler eğitimi uygulamalarının etkililiği bakımından olumlu bir sonuç olarak değerlendirilebilir.

Öğretmen adaylarının cinsiyetlerine göre değerler eğitimine yönelik tutum düzeyleri incelendiğinde erkek ve kadın öğrenciler arasında değer eğitimine yönelik olumlu inanç alt boyutunda kadınlar lehine anlamlı bir fark olduğu ortaya çıkmıştır. Buna karşın öğretmen adaylarının cinsiyetlerine göre değer eğitiminin gereğine inanç ve değer eğitimini içselleştirme alt boyutlarında ise anlamlı farklılık bulunmamıştır. Katılımcıların benzer eğitim seviyesinde ve aynı bölümde okumalarının, değerler eğitiminin gereğine inanç ve değer eğitimini içselleştirme konusuna benzer düzeyde tepkiler vermelerine neden olmasına karşın kadın ve erkeklere yüklenen toplumsal rollerdeki farklılıkların kadınların değerler eğitimine yönelik olarak erkeklere kıyasla daha olumlu inanç geliştirmelerine neden olmuş olabilir. Yılmaz ve Yılmaz (2017) tarafından yapılan sınıf ve okulöncesi öğretmenlerinin değer öğretimi hakkındaki görüşlerini değerlendirdikleri çalışmalarının sonucunda öğretmenlerin cinsiyet değişkeni açısından değer eğitimine ilişkin görüşlerinde anlamlı bir farklılık ortaya çıkmamıştır. Yaşaroğlu'nun (2014) sınıf öğretmenleri üzerinde yaptığı çalışma sonucunda öğretmenlerin cinsiyetlerine göre değer eğitimine yönelik tutumlarının farklılaşmadığ 1 , ancak kadın öğretmenlerin erkeklere göre daha olumlu bir tutuma sahip oldukları görülmüştür. Ayrıca Fidan (2009) tarafindan yapılan bir çalışmada öğretmen adaylarının değerler öğretimine ilişkin görüşleri incelenmiş ve değer öğretimine ilişkin görüşlerinin kadın öğretmen adayları lehine anlamlı düzeyde farklılaştığı tespit edilmiştir. Dilmaç, Bozgeyikli ve Çıkılı (2008) ile Altunay ve Yalçınkaya (2011) kadın öğretmen adaylarının erkek öğretmenlere göre bu konuya daha fazla önem verdikleri sonucuna varmışlardır. $\mathrm{Bu}$ araştırma sonuçları, bizim araştırmadan elde edilen bulguları destekler niteliktedir. Bilmez ve Tarkoçin'in (2017) okulöncesi öğretmenleri üzerinde yaptıkları çalışmanın sonucunda öğretmenlerin değerler eğitimine yönelik tutumlarının cinsiyete göre farklılaşmadığı ortaya çıkmıştır. Buna karşın erkek öğretmenlerin ortalamasının kadın öğretmenlerin ortalamasına göre daha yüksek olduğu görülmüştür. Benzer şekilde Vatansever Bayraktar ve Karakülçe'nin (2019) sınıf öğretmenleri üzerinde yaptığı çalışma sonucunda erkek öğretmenlerin puan ortalamasının kadın öğretmenlerinkine göre biraz daha yüksek olmasına karşın bu fark istatistiksel olarak anlamlı bulunmamıştır. Bu sonuçlar ise bizim araştırmamızdan elde edilen sonuç ile çelişmektedir.

Öğretmen adaylarının yaş ve sınıf değişkenine göre değerler eğitimine yönelik tutum düzeylerine bakıldığında değer eğitimini içselleştirme, değer eğitiminin gereğine inanç ve değer eğitimine yönelik olumlu inanç alt boyutlarında istatistiksel olarak anlamlı bir farkın ortaya çıkmadığı görülmüştür. Diğer bir ifade ile öğretmen adaylarının değerler eğitimine yönelik tutumlarının yaş ve sınıf düzeyi bakımından birbirine benzer olduğu söylenebilir. Bu araştırmada böyle bir sonucun ortaya çıkmasının nedeni olarak, araştırmamıza katılan öğretmen adaylarının yaş düzeylerinin birbirlerine yakın olmasından kaynaklanmış olabileceği düşünülmektedir. Bu çalışmanın sonucu öğretmen adaylarının yaş ve sınıf düzeyi açısından değerler eğitimine yönelik tutumlarında herhangi bir farklılığa işaret etmemiştir. Bu sebeple, kişilerin değerler eğitimine yönelik tutumlarının yaşla ve sınıf değişkeni ile yakından ilişkili olmadığı yapılmış araştırma sonuçları ile desteklenmektedir. Vatansever-Bayraktar ve Karakülçe'nin (2019) yapmış olduğu araştırmada sınıf öğretmenlerinin, yaş düzeylerine bağlı olarak değerler eğitimine ilişkin tutumlarının farklılaşmadığı görülmüştür. Benzer şekilde Bilmez ve Tarkoçin (2017) yaptıkları araştırma sonucunda okul öncesi öğretmenlerinin, yaşa göre değerler eğitimine yönelik 
tutumlarının farklılaşmadığı ortaya çıkmıştır. Öğretmenlik bölümüne yeni girmiş veya son sınıfa gelen öğretmen adaylarının, değerler eğitimi tutumlarının benzerlik göstermesi kişinin yaşının ve sınıf düzeyinin, sergileyeceği tutumda etkisinin olmadığı sonucunu ortaya çıkarabilir. Sonuç olarak öğretmen adaylarının üniversite geçirdikleri sürelerin, değerler eğitimine yönelik tutumları üzerinde kuvvetli bir etkisinin olmadığı söylenebilir. Bu sonucun da üniversitelerin beden eğitimi ve spor öğretmenliği programlarında karakter ve değerler eğitimi ile ilgili etkinlikler düzenlememelerinden ve öğrencilerin tutumlarını daha üst düzeylere çıkaracak derslerin seçmeli ders statüsünde kalarak sayıca yetersiz olmasından kaynaklandığı düşünülmektedir.

$\mathrm{Bu}$ araştırmadan elde edilen son sonuç ise anne ve babanın eğitim düzeyine bağlı olarak öğretmen adaylarının değerler eğitimine yönelik tutumlarında farklılık olup olmadığıdır. Sonuçlar öğretmen adaylarının değerler eğitimine yönelik tutumlarının anne ve babanın eğitim düzeyine göre farklılaşmadığını göstermiştir. Ailenin değerlerin oluşmasında önemli bir kurum olduğu bilinmektedir. Fidan (2009) araştırmalarından birinde öğretmen adaylarının değer öğretiminde genel olarak belirleyici etmenin aile olduğu ve okulda verilen değerlerin ailede pekiştirildiği fikrini paylaşmaktadır. Bir başka araştırmada ise öğretmen adaylarına değerleri kazandırmada ailenin önemli bir rol oynadığı ve bu konuda ailelerin eğitilmesi gerektiği belirtilmektedir (Yazar, 2012). Değerlerin yerleşmesinde annebabanın eğitim durumunun önemli olduğu yaygın olarak kabul edilse de araştırmamızda anne veya babanın eğitim düzeyinin beden eğitimi ve spor öğretmeni adaylarının değerler eğitimine yönelik tutumları üzerinde anlamlı bir fark yaratmadığı ortaya çıkmıştır. Anne ve baba eğitim düzeylerinin öğretmen adaylarının değerler eğitimine yönelik tutumlarını etkilememesinin nedeni olarak, ebeveynlerin eğitim düzeyinden kaynaklanan artıları ve eksileri çocuklarına benzer düzeyde yansıtmış olmaları olabilir. Altunay ve Yalçınkaya (2011) tarafından paralel bir sonuca ulaşılmıştır. Ebeveyn eğitim durumu açısından tutumlarda anlamlı bir fark olmadığını bulmuşlardır. Benzer şekilde bu araştırma, Eğilmez, Eğilmez ve Engür'ün (2018) müzik öğretmeni adayları üzerinde yaptığı çalışmada elde ettiği anne-baba eğitim durumlarının, değerler eğitimine yönelik tutumlar üzerinde anlamlı bir farklılık oluşturmadığı bulgusu ile paralellik göstermektedir.

Sonuç olarak; öğretmen adaylarının değerler eğitimine yönelik tutum düzeylerinin değer eğitimini içselleştirme, değer eğitiminin gereğine inanç ve değer eğitimine yönelik olumlu inanç alt boyutlarında sınıf, yaş ve anne-baba eğitim düzeyine göre değişmediği görülürken, öğretmen adaylarının sadece değer eğitimine yönelik olumlu inanç alt-boyutunda kadınlar lehine anlamlı bir farklılık gösterdiği saptanmıştır.

$\mathrm{Bu}$ durumda beden eğitimi ve spor öğretmen adaylarının değerler eğitimine yönelik tutumlarının farklı değişkenlerle araştırılması önerilmektedir. Ayrıca beden eğitimi ve spor öğretmeni adaylarının değerler eğitimine yönelik tutumları ile diğer öğretmenlik bölümlerinde öğrenim gören öğretmen adaylarının tutumlarının karşış̧̧ırılması için daha fazla araştırmaya ihtiyaç duyulmaktadır. Beden eğitimi ve spor öğretmeni adayları ile beden eğitimi ve spor öğretmenlerinin değerler eğitimine yönelik tutumlarının karşılaştırıldığı bir araştırma yapıldığında, değerler eğitiminin uygulanma düzeyine ilişkin önemli veriler elde edilmesinin olası olacağı düşünülmektedir.

\section{KAYNAKLAR}

Al Mamun, A., Rahman, M., Rahman, A. R. \& Hossaim, A. A. (2012). Students' attitudes towards English: The case of life science school of Khulna University. International Review of Social Sciences and Humanities, 3(1), 200-209.

Aladağ, S., \& Kuzgun, M. P. (2015). Sınıf Öğretmeni Adaylarının ‘Değer’ Kavramına İlişkin Metaforik Algıları. Sakarya Üniversitesi Eğitim Fakültesi Dergisi, (29): 163-193.

Altan, M. Z. (2011). Çoklu zekâ kuramı ve değerler eğitimi. Pegem Ĕgitim ve Öğretim Dergisi, 1(4), 54-57. 
Altunay, E. \& Yalçınkaya, M. (2011). Öğretmen Adaylarının Bilgi Toplumunda Değerlere İlişkin Görüşlerinin Bazı Değişkenler Açısından İncelenmesi. Kuram ve Uygulamada Ĕğitim Yönetimi, 17(1), 5-28.

Alyılmaz, C. \& Alyılmaz, S. (2014). Amirbek Turatoviç Muratov’dan Yenisey’e sesleniş. Uluslararası Türkçe Edebiyat Kültür Ë̆itim Dergisi, 3(1), 68-74.

Bilmez, B., \& Tarkoçin, S. (2017). Okul Öncesi Öğretmenlerinin Değerler Eğitimine Yönelik Algılarının İncelenmesi (Bingöl İli Örneği). Bingöl Araştırmaları Dergisi, 3(2), 113-127.

Blase, J. J. (1983). Teachers' Perceptions of Moral Guidance. The Clearing House, 56(9), 389-393.

Chou, C. P., \& Bentler, P. M. (1995). “Estimates and Tests in Structural Equation Modelling”, Rick H. Hoyle (Ed.). Structural Equation Modelling: Concepts, Issues and Applications, Thousand Oaks, CA: Sage.

Coşkunserçe, O. (2020). Değerler Eğitiminde Video Blog Kullanımı. Değerler Eğitimi Dergisi, 18(40), 307-343.

Curan, P. J., West, S. G., \& Finch, J. F. (1996). The Robutness of Test Statistics to Non- Normality and Specification Error in Confirmatory Factor Analysis. Pyschological Methods, 1(1), pp. 16-29.

Çetin, F. (2018). Değer Eğitimine Yönelik Tutum Ölçeği (DETÖ) Geçerlik ve Güvenirlik Çalışması. Türkiye Sosyal Araştırmalar Dergisi, 22(193), 323-341.

Dilmaç, B., Bozgeyikli, H., \& Çıkılı, Y. (2008). Öğretmen adaylarının değer algılarının farklı değişkenler açısından incelenmesi. Değerler Ĕgitimi Dergisi, 6(16), 69-91.

Eğilmez, Ö., Eğilmez, H. O., \& Engür, D. (2018). Attitudes of Pre-Service Music Teachers towards Value Education in Turkey. International Journal of Evaluation and Research in Education (IJERE), 7(1), 11-16.

Ergün, M. (1994). Eğitim Sosyolojisine Giriş. Ankara: Ocak Yayınları.

Fidan, N. K. (2009). Öğretmen adaylarının değer öğretimine ilişkin görüşleri. Kuramsal Eğitim Bilim Dergisi, 2(20), 1-18.

Fraenkel, J. R., Wallen, N. E. \& Hyun, H. H. (2018). How to Design and Evaluate Research in Education (10th ed). New York: McGraw-Hill.

İlhan, D., \& Karataş, H. (2015). An analysis on motivational beliefs and attitudes of undergraduates regarding learning English. International Journal of Educational Researchers, 6(2), 1-14.

Kağıtçıbaşı, Ç., \& Cemalcılar, Z. (2014). Dünden bugüne insan ve insanlar: Sosyal psikolojiye giriş. İstanbul: Evrim Yayınevi.

Koç, A., \& Budak, Y. (2021). Manevi Değerlerin Kazanımında Sosyal ve Kültürel Faaliyetlerin Etkisi Ölçeği: Geçerlik ve Güvenirlik Çalışması. Din Bilimleri Akademik Araştırma Dergisi, 21(1), 323-349.

Kozikoğlu, İ. (2018). Okul öncesi öğretmenlerinin değerler eğitimine ilişkin tutum ve görüşlerinin incelenmesi. Uluslararası Türkçe Edebiyat Kültür Eğitim Dergisi, 7(4), 2698-2720.

Köylü, M. (2016). Teoriden Pratiğe Değerler Ĕ̈itimi. Ankara: Nobel Yayıncılık Ulusoy.

Kulaksızoğlu, A., \& Dilmaç, B. (2000). İnsani değerler eğitimi programı. M.Ü. Atatürk Eğitim Fakültesi Eğitim Bilimleri Dergisi, 12(12), 199-208.

Özgüven, İ. E. (1994). Psikolojik testler. Ankara: Yeni Doğuş Matbaası.

Şahin, N. (2019). Karakter ve değerler eğitimi dersinin Türk dili ve edebiyatı öğretmeni adaylarının değer eğitimine yönelik tutumları üzerindeki etkisinin incelenmesi. Rumelide Dil ve Edebiyat Araştırmaları Dergisi, 15, 63-78. DOI: 10.29000/rumelide.580457.

TDK. (2015). Türkçe sözlük. Ankara: TDK Yayınları.

Vatansever Bayraktar, H,. \& Karakülçe, N. (2019). İlkokul Yöneticilerinin ve Sınıf Öğretmenlerinin Değerler Eğitimi Tutumlarının İncelenmesi. Akademik Sosyal Araştırmalar Dergisi, 6(35), 137-157.

Yalar, T. (2010). İlköğretim sosyal bilgiler programında değerler ĕgitiminin mevcut durumunun belirlenmesi ve ögretmenlere yönelik bir program modülü geliştirme. Yayımlanmamış doktora tezi, Mersin Üniversitesi/ Sosyal Bilimler Enstitüsü, Mersin.

Yaşaroğlu, C. (2014). Sınıf öğretmenlerinin değer eğitimine yönelik tutumlarının çeşitli değişkenler açısından incelenmesi. The Journal of Academic Social Science Studies, 27, 123-134.

Yazar, T. (2012). Öğretmen adaylarının değerler hakkındaki görüşleri. Pegem Eğitim ve Öğretim Dergisi, 2(1), 61-68.

Yazıcı, K. (2006). Değerler ĕgitimine genel bir bakış. Türklük Bilimi Araştırmaları, 19, 499-522.

Yazıcı, M. (2013). Değerler Eğitimine Gönüllü Katılan Öğretmenlerin Profili ve Görüşleri. The Journal of Academic Social Science Studies, 6(2), 995-1023.

Yıldırım, S. G. (2019). Değerler ĕgitimine yönelik bir model önerisi: Değer içselleştirme. Bursa Uludağ Üniversitesi Eğitim Bilimleri Enstitüsü İlköğretim Ana Bilim Dalı. Doktora Tezi, Bursa. 
Yılmaz, M., \& Yılmaz, Ö. M. (2017). Sınıf ve Okul Öncesi Öğretmenlerinin Değer Öğretimine İlişkin Görüşleri. Bartın Üniversitesi Eğitim Fakültesi Dergisi, 6(2), 737-748. 